\title{
インフルエンザワクチンの免疫効果に関する研究
}

第 1 報 ワクチン抗原の免疫力価子被接種集団の 抗体産生との関係

\section{Evaluation of Influenza Virus Vaccine}

I. The Interrelation of Antigenic Potencies of Influenza Virus

Vaccine to Antibody Response in Human Beings

Received the Vaccine

札幌医科大学衞生学教室（主任 金光正次教授）

平保

Tamotsu Taira

Department of Hygiene, Sapporo Medical College (Director: Prof. M. Kanamitsu)

\begin{abstract}
緒言
インフルエンザワクチン（以下ワクチンを略記）の接 種による血清抗体の産生については最近に执いても多数 の研究1-91 があり，一般にワクチンの力価が高い添でと れに対する抗体の産生む良好なととが認められている。 しかし教室の藤谷 ${ }^{7}$ はワクチンを人体に集団的に接種し

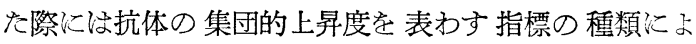
り，その価とワクチンの力価の強さとが必ずしも比例し ないとと学指摘し，その理由を考察するとともに，抗体 の集団的上界度学判定する新たな指標学提案した。しか し彼の報告では使用したワクチンの抗原力価柱, 我国で

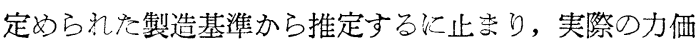
測定学行つていない。従つてとの問題はとの点执いて 未だ検討すべき余地が残されている。よつて私は野外接 種実験により，ワクチン力価としれにょる抗体の集団的 上昇との関係を定量的に観察し, 藤谷の指摘した点を検 討しょろと試みた。
\end{abstract}

\section{実験方法}

\section{1. 対象集団}

研究の対象として選んだ集団は, 札幌市幌南小学校男 女生徒 $(3,4,5$, 年) 約 90 名, 同市中央電報局男子 職員（20〜35才）及び同市交通局男子職員（20〜50才） 各及約 60 名である。

\section{2. 使用ワクチン，接種量及び接種方法}

千葉県血清研究所製 Lot. No. 10及び武田薬品工業製
Lot. No.7のワクチン学使用し炎。とれ性をもに P R 8, FMI, 及び Lee ウイルス抗原喜む 3 種混合ワ クチンである。

本実験では干葉血清研究所製ワクチンを幌南小学校生 徒の集団には $0.5 \mathrm{cc}$ 上䀯皮下に，中央電報局職員には同 じワクチンを $0.1 \mathrm{cc}$ 上膊皮内にそれぞれ 1 回接種した。 また交通局職員には武田薬品製ワクチンを 1 回 $1.0 \mathrm{cc}$ 上 膊皮下に接種した。

\section{3. 抗体測定法}

小学校生徒集団に対してはワクチン接種の直前と14日 及び45日後, その他の集団に対しては接種直前乞14日後 に採血し，分離した血清を $56^{\circ} \mathrm{C}, 30$ 分加熱非働化した後 ワクチンに含紊れている各抗原ウイルス即ちPR $8, \mathrm{~F}$ M 1, 及び Lee 株泣対する抗体学血球凝集抑制 (H I) 反応によつて測定した。抗原は各ウイルスの感染睬化鶏 卵の漿尿液党用い, 各血清の 2 倍階段稀釈列 $0.25 \mathrm{cc}$ 亿 3 単位の上記抗原 $0.25 \mathrm{cc}$ 加光，とれに $1 \%$ のワワトリ赤 血球浮遊液を駒込ピペットで 2 滴混じ, 室温に 1 時間放 置した後の管底の血球凝集像仗よつて判定した。抗体価 は福見, 山本等の方法汇従い抗原の終未稀瀵 1 単位认扝 心て血球凝集を抑制する血清の最大稀釈倍数の対数で表 わした。

\section{4. ワクチンのカ価測定法}

使用したワクチンの各ウイルス抗原の力価はマウスに おりるHI抗体及び中和抗体の産生状況によつて涀定に, た。即与各ワクチンの原液を体重10２0 gのマウス15p

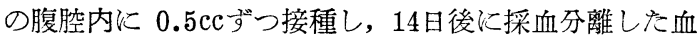


清孛プールして $56^{\circ} \mathrm{C}, 30$ 分加熱非働化した後, $\mathrm{H}$ I 抗体 は前記の方法汇從つて測定し, 抗体価は 3 単位のウイル 又抗原使用に招ける血球凝集を抑制する血清の最大稀釈 倍数で現わした。

また中和抗体の測定は藤谷" の方法に従いRoller tube による組織培養法を用いて行つた。即与孵化15日卵の墏 尿膜の 1 片 $\left(1.5 \sim 2.0 \mathrm{~cm}^{2}\right)$ を Fulon 氏液 $(\mathrm{pH} 7.2)$ $1.0 \mathrm{cc}$ に浮遊したもの学培地とし, 抗体測定は 4 倍階段 に稀釈した血清とウイルス液を混合して, $37^{\circ} \mathrm{C}$ に 30 分放 置し後, その $0.2 \mathrm{cc}$ を上記の培地に加光た。とれ在 $37^{\circ} \mathrm{C} て ゙ 48$ 時間迴転培養 ( 1 時間 25 回転) してから組織片 定除いた培液に $1 \%$ ワワトリ血球浮遊夜を駒込ピペット で 2 滴混和し, 室温に 2 時間放置した後に管底の血球凝 集像によつて判定した。培地は各血清稀釈列に対して 5 本用い，乙れと同時に使用したウイルスの感染価を同様 の方法で測定した。

血清中和抗体価㤝 Reed and Muench の方法を用い, 100 T C I D 50 のウイルスに対する50\%中和の血清稀积 倍数の対数で表わした。

\section{5. 抗体上昇度の判定方法}

抗体の集団的上昇度音判定するに当つては次の 4 種の 指標学用いた。

i）抗体上昗率。ワクチン接種後のH I 価が接種前の 価に比べて，4倍以上上昇したものの全数に対する割 合。

ii) 平均上昇倍数。各個体の H I 価の上昇倍数の幾何 平均。

iii）ワクチン接種前後に打汀当平均抗体価。

vi）集団免疫指数 $(X)$ 。藤谷 ${ }^{n} の$ 方法江従い各抗原ウ イルスに対するH I 抗体価の集団変動に適合する回帰式 在最小自乗法汇よつて計算し直線回帰の仮説が $5 \%$ の危 険率で棄却されない場合は, 回帰直線が基準線と交わる

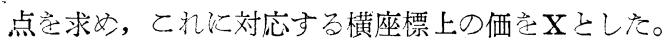

\section{成 績}

\section{I. 使用ワクチンの各ウイルス抗原のカ価}

この実験使用したワクチンに含まれるPR 8，FM 1, 及び Lee 抗原の力価をマウス妾用いて検定した成 績以第 1 表に示すどとくである。即ち千葉血清研究所及 び武田薬工製ワクチンともに，PR 8 抗体とFM 1 抗体 の産生注著明であるが, Lee 抗体の産生注これに比べ てかなり尖つている。この傾向は中和抗体と H I 抗体の 区別なく認められ，両種抗体の高さの間には平行的な関 係がある。現行のワクチン製造基準辸゙, 本ワクチ
ンはPR 8 抗原 $450 \mathrm{CCA}, \mathrm{FM} 1$ 及び Lee 抗原㳘上 むに $300 \mathrm{C} \mathrm{CA}$ 単位含含を規定されている。従つてP $\mathrm{R} 8$ 抗体の上昇が最も高いのは当然であるが，FM1抗 体己 Lee 抗体の上昇の間にこのよ弓な著しい差異の現 われたととは理解しがたい。との理由としてはワクチン 製造江用いた Lee 株ウイルスの抗原性が 低下していた こと，本抗原の実際の含有量が 少なかつたこと，及び Lee 抗体の上昇が FM 1 抗体の上昇に比べて遅延したて 々なぞが考えられるが，いずれも確証はない。以上の成 績によれば千葉, 武田製のワクチンは Lee 抗原䘮除く 各抗原の力価の点ではあ⿱ る著しい差がないものと認め られる。

\section{第1表 マウスによるワクチンのカ価検定成績}

\begin{tabular}{|c|c|c|c|c|}
\hline $\begin{array}{l}7 \\
ク \\
x \\
y \\
\end{array}$ & 抗 体 & $\begin{array}{r}\text { PR } 8 \\
450 \mathrm{ccA}\end{array}$ & $\begin{array}{l}\mathrm{FM} 1 \\
300 \mathrm{ccA}\end{array}$ & \begin{tabular}{|c} 
Lee \\
$300 \mathrm{ccA}$
\end{tabular} \\
\hline $\begin{array}{l}\text { 千血 } \\
\text { 葉清 } \\
\text { 製 }\end{array}$ & $\begin{array}{l}\text { 中 和 抗 体 } \\
\mathrm{H} \text { I 抗 体 }\end{array}$ & $\begin{array}{l}\cdots \\
1024\end{array}$ & $\begin{array}{l}1000 \\
1024\end{array}$ & $\begin{array}{l}25 \\
64\end{array}$ \\
\hline $\begin{array}{l}\text { 武薬 } \\
\text { 田品 } \\
\text { 製 }\end{array}$ & $\begin{array}{l}\text { 中 和 抗 体 } \\
\mathrm{H} \text { I 抗 体 }\end{array}$ & $\begin{array}{l}\cdots \\
1024\end{array}$ & $\begin{array}{l}800 \\
512\end{array}$ & $\begin{array}{r}50 \\
256\end{array}$ \\
\hline
\end{tabular}

\section{II. ワクチンを人体に集団的に接種 した際の抗体上昇}

\section{状況}

\section{a) ワクチン $0.5 \mathrm{cc}$ を皮下に接種した場合}

小学校生徒の集団に千葉血清研究所製ワクチンを 0.5 cc皮下に 1 回接種し, 14 日後, 及び45日後汇お汀るH I 抗体の集団的上昇度を前述の各指標によつて表わすと第 2 表のごとくである。まず14日後の成績をみると抗体上 昇率ではPR 8 抗体 $89.8 \%$ で最も高く, ついで Lee 抗 体がやや低いが，FM1抗原の力洒柱 P R 8 抗原と等し いと拘らず，乙㣗対する抗体上昇率は著しく低い。こ

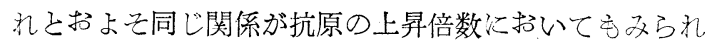
るが，接種後の平均抗体価は反対に F M 1 抗体が最も高 い。次にワクチン接種前の抗体の高さと上昇度との関係

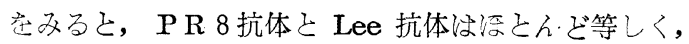
またその上昇倍数は力価の高い R R 8 抗原江対する抗体 の方が明らかに優れているが，抗体上昇率では耐者の間 にそれ㴽ざ著しい差はみられない。これに対して接種前 の価が最も高いFM 1 抗体は, 抗原力価がPR 8 抗原に 匹敵するに拘らず，その上昇率，上昇倍数已もに他抗体 より著しく低い。し六し接種後の平均抗体洒法, 接種前 最も高かつた FM 1 抗体が最高の值を示している。従つ てとれらの指標の示卞抗体上昇度とワクチン抗原の力価 
この間には，明確な関係を見出すことができない。

次化各抗体の集団的上昇傾向行適合学回帰式已求幼 ると，PR 8 抗体ではワクチン接種前の抗体価の分布範 囲が著しく狭いため回帰式を計算するととは不可能で あるが，FM1抗体及び Lee 抗体の集団的変動仗已も

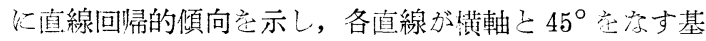
潐線之交わる点化対応する 横軸上の価 $\mathrm{X}$ (集団免疫指

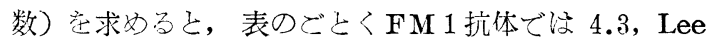
抗体では 3.7 とな前者の価が明らか心高く, 雨者の関 係愉項のマウスによつて測定した各ワクチン抗原の力 価の高さとよく平行している。従つて抗体上昇率，平均 上昇倍数，接種後の平均抗体価が使用したワクチン抗原 の力価々合致しないのは, ワクチン接種前の各抗原ウイ ルス汇詨する既有抗体の分布の差異によるものと考方ら れる。次に, ワクチン接種より45日後の成績をるると, FM 1 及び Lee 抗体の集団变動洛同様に直線回帰的傾 向定すのみならず，それぞれの判定指標の示す各抗体 の上昇度の順位も，上述の14日後の成績と全く等しい。 しかし14日後に比べて45日後の抗体価疷いずれを明らか 飞低下して招り，特江 FM 1 抗体の上昇率は僅か儿 3.4

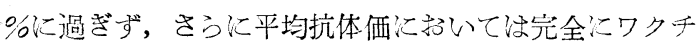
ン接種前の価汇復帰している。抗体の低下注X值に扮い ても同様であるが,表のごとくな扔 FM 1 抗体では 3.6， Lee 抗体では 3.3 示し, ふなり高い值学維持してい

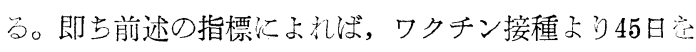
経過すればFM 1 抗体洨漂とんど接種前の值に低下寸る と判定されるが， $\mathrm{X}$ 值を指標とすれ彷ワクチンの本抗体 の上㫧に及活した効果が，な持相当の高さで存続してい

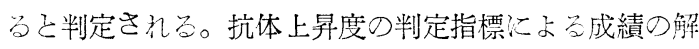
积の差異は, この点化扮いても明らかである。

\section{第 2 表 ワクチン $0.5 \mathrm{cc}$ 皮下接種による抗体変動}

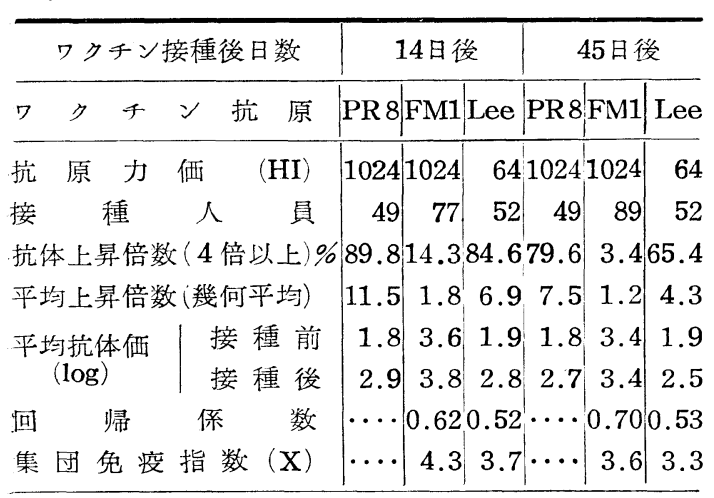

平均抗体価はウイルス抗原 1 単位使用に扣ける被 検血清の抑制指数（福見，山本法）にて表わす

\section{b) ワタチン $0.1 \mathrm{cc}$ を皮內に接種した場合}

成人の集団汇前項の害駼汇用いたと同じワクチン空 $0.1 \mathrm{cc}$ 皮内代接種し，各抗体の産生学前述已同じ方法て

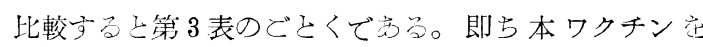
$0.5 \mathrm{cc}$ 皮下接種した場合に比べて各抗体の上昇度は明ら 代低いが，抗体上昇率，平均上昇倍数主指標とした上 昇度の順位隹前項の成績と全く同様にP R 8 抗体が最高 で, 以下Lee, FM 1 抗体の順減弱している。しかし 接種後の平均抗体価々前項の成績と異なり, P R 8 抗体 が最己高い。次优体価の集団的変動定及ると，乙の集

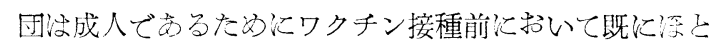
んどがPR 8 株ウイルスに対する抗体它保有しており,

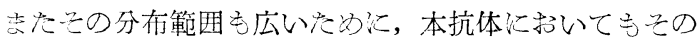
集団的上昇傾向学観察することができた。その成績は表 に2るように各抗体ともに直線回帰的化上昇し, それに 基いて求內たP R 8 と FM 1 抗体のX值は湶とんど等し いが, Lee 抗体の值快とれに比べて, 明らか飞低く各抗 原の力価の高さとよく平行している。即ちこの成績は $\mathrm{X}$ 值孞抗体上昇度在判定す極放て適印な指標であるとと 危証明している。

\section{第 3 琵 ワクチン $0.1 \mathrm{cc}$ 皮內接種による抗体変動}

\begin{tabular}{|c|c|c|c|}
\hline ワクチン接種後日数 & \multicolumn{3}{|c|}{14 日 後 } \\
\hline ワクチン 抗 原 & PR 8 & FM 1 & Lee \\
\hline 抗 原 力 価 (HI) & 1024 & 1024 & 64 \\
\hline 接種人 & 62 & 63 & 49 \\
\hline 抗体上昇率 ( 4 倍以上) \% & 61.3 & 9.5 & 40.8 \\
\hline 平均上昇倍数 (幾何平均) & 4.7 & 1.4 & 2.6 \\
\hline 平均抗体価 接 種 前 & 2.7 & 3.0 & 2.6 \\
\hline 接 種 & 3.4 & 3.1 & 3.0 \\
\hline 回 帰 係 数 & 0.36 & 0.77 & 0.52 \\
\hline 集団兔疫指数 (X) & 3.8 & 3.7 & 3.4 \\
\hline
\end{tabular}

\section{c) ワクチン $1.0 \mathrm{cc}$ を皮下に接種 した場合}

第 4 表注成人の集団淮田薬工製ワクチン觉 $1.0 \mathrm{cc}$ 皮 下に接種した際の，14日後に扔けるFM1及びLee 抗

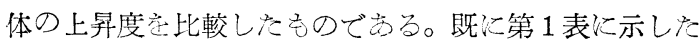
ように, 本ワクチン中の Lee 抗原の力価次, 前項宗て の実験汇使用したワクチンに比べてやや高い。表に見る ようにこの実験注いても接種前の水準の高いFM 1 抗 体の方が, 上昇率, 上昇倍数ともに Lee 抗体ょり低い が, 前項灾での実験成績に比べて両者の值が著しく接近 している。とれは接種量を増したために既有の值の高い FM1 抗体に抬いても上昇が著しいためである。しかし 
第 4 表 ワクチン $1.0 \mathrm{cc}$ 皮下接種による抗体変動

\begin{tabular}{|c|c|c|c|}
\hline \multicolumn{2}{|c|}{ ワクチン接種後日数 } & \multicolumn{2}{|c|}{14 日 } \\
\hline ワクチ & У抗 原 & FM 1 & Lee \\
\hline 抗 原 力 & 価 $\quad(\mathrm{HI})$ & 512 & 256 \\
\hline 接＜wide>種 & 人 員 & 37 & 51 \\
\hline 抗体上昇率 & 4 倍以上) $\%$ & 51.3 & 56.9 \\
\hline 平均上昇倍 & (幾何平均) & 3.3 & 4.1 \\
\hline 平均抗体価 & 接 種 前 & 3.2 & 2.6 \\
\hline$(\log )$ & 接 種 後 & 3.7 & 3.2 \\
\hline 帰 & 俰 数 & 0.48 & 0.35 \\
\hline 集 団免 疫 & 指 数 $(\mathrm{X})$ & 4.2 & 3.6 \\
\hline
\end{tabular}

X值を指標にすれぼ，力価の高いFM 1 抗原に対する抗 体の方が明らかに高く，ワクチンの接種量を增してもこ の指標の特性は失われない。

\section{III. ワクチンの接種量が抗体の 集団的上昇傾向に及} ぼす影響

上述の成績から FM 1 抗体について，ワクチンの接種 量の差異が本抗体の集団的上昇傾向にどのように影響す るかを示したものが第 1 図及び第 5 表である。図におい て抗体価の集団的変動に当はめた回帰直線の位置とその 傾斜をみると, $1.0 \mathrm{cc}$ 及び $0.5 \mathrm{cc}$ を接種後14日目の平均

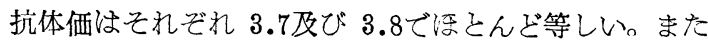
その際の回帰直線が基準線と交はる点即ちX值も 4.2及， び 4.3で涂とんで等しいが, その回帰系数は 0.48 と 0.62 で, 傾斜は $1.0 \mathrm{cc}$ を接種した時の方が緩かである。こ のととはワクチンによつて上昇を誘発される既存抗体の 高さの上限值は, との程度の接種量の差ではほとんざ変 らないが, 既有のFM 1 抗体の低いものでは，接種量が多 い添ど抗体の上昇も著しいととを示している。とれ対
して接種量を $0.1 \mathrm{cc}$ に減じた場合の 14 日後の平均抗体 価は $3.1 て ゙$ 前郡に比べて明らかに低く,またX值も 3.7 に低下寸るとともに回帰系数は 0.77 亿増大し, 直線の傾 斜が著しく急峻になつている。即ちかかる微量のワクチ ンでは抗体の上昇は甚だ微弱で，特に接種前既に本抗体 が高い者に対しては抗原刺战の効果は法こんどないと解 される。Lee 抗体に颃いて観察した成績も扣よそこれ々 等しいが, FM1 抗体の場合に比べてワクチンの接種量 の差による抗体の変動傾向の変化はあまり著明でない。

\section{第 5 表 ワクチン接種量と FM1 抗体の 集団的上昇傾向との関係 (14日後)}

\begin{tabular}{c|c|c|c|c|c}
\hline $\begin{array}{c}\text { ワクチン } \\
\text { 接種量 }\end{array}$ & $\begin{array}{c}\text { 接種 } \\
\text { 方法 }\end{array}$ & $\begin{array}{c}\text { 接種 } \\
\text { 人員 }\end{array}$ & 回帰係数 & $\begin{array}{c}\text { 集団免疫 } \\
\text { 指数 }(\mathrm{X})\end{array}$ & $\begin{array}{l}\text { 14日後の平 } \\
\text { 均抗体価 }\end{array}$ \\
\hline $1.0 \mathrm{cc}$ & 皮下 & 37 & 0.48 & 4.2 & 3.7 \\
$0.5 \mathrm{cc}$ & 皮下 & 77 & 0.62 & 4.3 & 3.8 \\
$0.1 \mathrm{cc}$ & 皮内 & 63 & 0.77 & 3.7 & 3.1 \\
\hline
\end{tabular}

\section{考按}

最近のインフルエンザワクチンの研究は，抗原とする ウイルス株の選択, 免度力価の高いワクチンの製造方法 とともに，生体に対する感染防禦の效果に注がれてい る24)-299。そのうちワクチンの力価の高さは現行基準によ ればこれを接種したマウスに打ける中和抗体の産生度か ら定められるものであるが，近年はこれとともに直接人 体に対寸る野外接種実験比研究が広く行われてい る。しかし人体は実験動物と異なり通常各型のイ, ウイ ルスに対する抗体它保有しており，乙の既有抗体の高さ がワクチンによる抗体の上昇態度に著しく影響するとと が知られている。従つて人体接種の際の抗体上昇状況に よつてワクチンの力価を判定する場合には，接種前に昖

第 1 図 ワクチン接種量の変化による FM 1 抗体の菓団変動（接種後14日）

$1.0 \mathrm{cc}$ 接種 $(\mathrm{N}=37) \quad 0.5 \mathrm{cc}$ 接種 $\quad(\mathrm{N}=77)$ $0.1 \mathrm{cc}$ 接種 $\quad(\mathrm{N}=63)$
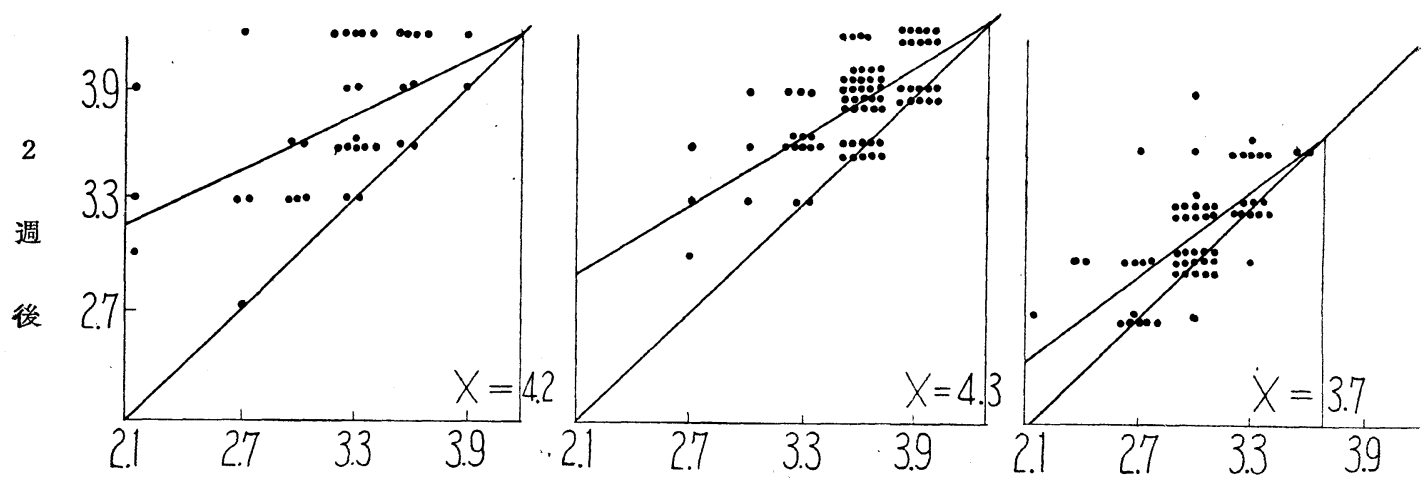

接

種

前 


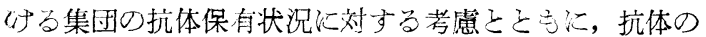
上昇度をどのような基準で判定するかが重要な問題とな るが, 従来の報告にはとの点付対する考虑が甚だ少ない ようである。私は本報に抏いて，ワクチン抗原に対する 抗体在既汇保有している集団にそのワクチンを接種した 際, 抗原刺战によつて上昇定うながされる既有抗体の理 論的上限值を指標として, ワクチンの免疫力価と抗体の 集団的上昇との関係学観察した。その結果上述の成績仙 示したごとく，X値はワクチン接種前に招计る集団の既 有抗体の高さに影響されるととなく，穴の抗原力価とよ く平行するととを認めた。こ机往従来抗体の上昇度学判 定する際用いられていた抗体上昇率，平均上昇倍数，ワ クチン接種後の平均抗体価等とは質的に異なる新しい判 定指標である。

しかしこの方法を適用至る際汇法若干の条件がある。 即古上述のX值の性状から明らかなように，乙の方法䒕 適用されるそは抗体の集団変動の傾向が直線的な場合に 限られている。既に金光等 ${ }^{22223}$ 方指摘したように, ワク チン接種前の既有抗体が低い值から著しく高い値心わた つて分布している集団では，ワクチンにより低い抗体注 上昇するのに対して, 高い抗体仿変動しがたいために, その集団的変動傾向埌基準線汇漸近する曲線で表わされ るととになるので理論上X值淰求文られない。 Hirst 等111の成績仗その 1 例已考光ら㣗る。ま集団の既有抗 体が著しく狭い值の領域江分布している場合では, 抗体 つ変動傾向に当てはめた回帰直線の信頼性が問題飞な り, 従つててれから求めたX值にも誤差が大きくなる。 このようにX值による抗体上昇度の判定に程種々の制約 があるが，な抒他の方法に比べて著しい特微交含んでい 20

即ちとの方法によればX值とこもに，抗体の集団的変 動㑯向在表わす回帰直線の傾斜が，抗体上昇の性状の指 標となる事である。この指標の忘用価値は本報のワクチ ンの接種量と抗体上昇との関係至比較した成績に抏いて 最も効果的记示された。Weller 等 ${ }^{18)}$ ，Bruyn ${ }^{19)}$ 等, 甲野

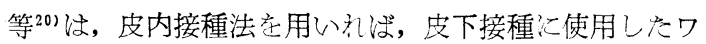
クチン量より格段に少ない量です，乙れに匹敵する抗 体の上昇を示与と述べているが, Appleby 等 ${ }^{1 i)}$, 福胃 等 ${ }^{9}$, は $1.0 \mathrm{cc}$ の皮下接種汇比べて $0.1 \mathrm{cc} の$ 皮内接種 による抗体上昇に明らか溦弱で市ると報じている。志 た McLean 等 ${ }^{30}$ は同じ接種法を用いた場合では, ワク チンの量を10倍に増してもそれによつて到達した抗体の 高さの增加は, 接種量の 2 乗根あるいは 3 乗根比比例す るにすぎなといつている。以上のどとくしの問題につ
いての諸家の見解㥙必ずしも一致しないが，とれはワク チン定接種する前の既有抗体の高さととも㐳, 抗体上昇 度导判定する指標が異なるとと汇起因するものと考充ら れる。

私以本報で FM 1 抗体について観察した成績によれ 壮, ワクチンの量芼 $1.0 \mathrm{cc}$ 方ら $0.5 \mathrm{cc}$ 汇減じても, そ 㣗によつて到達した平均抗体価の間には掭とんど差異京 認めない。またその際のX值汇も深とんで差異がなく， これ㳊それぞれの接種量しよつて上昇学誘起された既有 のFM 1 抗体の上限值に湾化がないとと意味してい る。

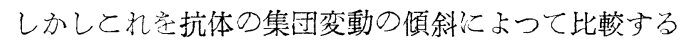
と, 接種量を減ずる良つてその傾斜が急峻となり, こ れはワクチン抗原に対する既有抗体の低い者漂ぞ, 接種 量の低下の抗体上昇化及济す影響が強いととを示してい る。ささら $0.1 \mathrm{cc} の$ 皮内接種ではその傾斜がさらに急 峻になるとともに, X值も著しく低下し, 免疫効果の低 いととを示している。

即ちこの判定方法によれ洼, ワクチンの免疫力洒, 接 種量, 接種方法の差異による抗体の集団的上界状沉の微 細な変化を，数量的代表わすととができる。，穼たこの考

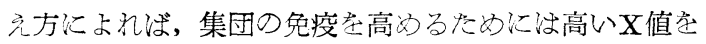
示すワクチンを用いるとともに, その際の抗体変動の傾 斜がなるべく緩やがなるような接種方法它採用する必 要がある。そのためには上述のどとくワクチンの接種量 を增すととも有効であるが, 最近清水 ${ }^{311}$ は腸チフスワク チンによる抗体の集団的変動学観察して, ワクチンの再 接種が既有抗体の低い者の抗体上昇学著しく増強すると 己さ指摘しており，インフルェンザワクチンの場合にも 同様の現象があるのではないかと考えられる。

な打本報汇执いて免疼、ウスの H I 抗体已中和抗体 の上昇がよく平行するととを認めたが，乙れは Hirst

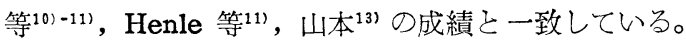
人体江打る両種抗体の集団的上昇態度の関係泟ついて は次篇で報告する。

\section{結 語}

1） P R 8, FM1，Lee，3 種混合インフルエンぜ ワクチン音人間の集団に接種し, 各抗原ウイルスの免疫 力価とこれに対するHI抗体の集団的上昇状況を各種の 指標によつて比較した。

2) 従来用いら㣗ている抗体上昇率, 平均上昇倍数, 並びに接種前後の平均抗体価の変化沉よる判定では, 抗 体上昇度とワクチン抗原の力価の高さとは必ずしも一致 しない。 
3）とれに対して我々の提唱する集団免疫指数 $\mathbf{X}$ 值は ワクチン抗原の力価とょく一致した。

4）抗体の集団的変動に対する回帰直線の傾斜は, $\mathrm{X}$ 值とともにワクチンの接種量及び接種方法が抗体産生に 及ぼす効果定測る適切な指標であること学認めた。

この研究は文部省科学研究費の補助を受けた。

\section{交献}

1) Francis, T. Jr. : Bull. W. H. O. $18: 275,1953$.

2) Meiklejohn, G. et al. : Am. J. Hyg. 55 : 1, 1952.

3) Meiklejohn G. et al. : Ibd. $55: 12,1952$.

4) Hennessy, A. V. et al. : Ibd. $58: 165,1953$.

5) Meiklejohn, G. et al. : Ibd. $59: 241,1954$.

6) Davenport, F. M. et. al. : Am. J. Publ. Health. 45 : 1138, 1955.

7) 藤谷: 札幌医学雑誌, $7: 340,1954$.

8) Fukumi, M. et al. : Jap. J. Med. Sci. Biol. $7: 345,1954$.

9）福見他：日本医事新報，1671，1956.

10) Hirst, G. K. et al. : J. Immunol. $45: 285$, $1942 \mathrm{a}$.

11) Hirst, G. K. et al. : J. Exp. Med. $75: 49$, $1942 \mathrm{~b}$.

12) Henle, G. \& Henle, W. : Ibd. $84: 623,639$, 1946 b.

13) 山本: 日本医学, $4318,1949$.

14) Salk, J. E. et al. : Am. J. Hyg. $42: 57$,
1945.

15) Hirst, G. K. et al. : Ibd. $42: 45,1945$.

16) Magil, T. P. et al.: Ibd. 42:94, 1945.

17) Appleby, J. C. et al. : Lancet $6670: 1384$, 1951.

18) Weller, T. H. et al. : Proc. Soc. Exp. Biol. Med. 67 : 96, 1948.

19) Bruyn, H. B. et al. : Am. J. Dis. Child. 77 : 149, 1949.

20）甲野他：インフルェンザ委員会，1.ワクチンの 野外実験, 1953 .

21) 操他： Ibd.

22）金光：公衆衛生，20：(3) 1, 1956.

23）金光他：医学々生物学. 29 : (5) 196, 1953.

24) Influenza. A Review of Current Research. WHO. Geneva, 1954. P. 125.

25) Davenport, F. M. et al. : Am. J. Hyg. 64 : 289, 1956.

26) Finland, M. et al. : Ibd. 64 : 289, 1956.

27) Philip, R. N. et al. : Am. J. Publ. Health $44: 34,1954$.

28) Davenport, F. M. \& Hennessy, A. V.: J. Exp. Med. 104 : 85, 1956.

29) Prezesmycki, Et al. : Ann. Inst. Pastur 91 (Suppl) : 9, 1956.

30) Mclean, I. W. et al. : J. Immunol. 56 : 109, 1947.

31) 清水: 日本衛生学雑誌, $11: 110,117,1956$.

（受付：1957年 9 月16日） 